\title{
Glycemic Variability and Vascular Complications in Patients with Type 2 Diabetes Mellitus
}

\author{
Martin Caprnda ${ }^{1}$, Dasa Mesarosova ${ }^{1}$, Pablo Fabuel Ortega ${ }^{1}$, Boris Krahulec ${ }^{1}$,Emmanuel Egom ${ }^{2}$, \\ Luis Rodrigo ${ }^{3}$, Peter Kruzliak ${ }^{4}$, Ioana Mozos ${ }^{5}$, Ludovit Gaspar ${ }^{1}$ \\ 1 1st Department of Internal Medicine, School of Medicine Comenius University, Bratislava, Slovakia \\ 2 Department of Clinical Medicine, Education Division, Trinity College Dublin, Dublin, Ireland \\ ${ }^{3}$ University of Oviedo, Central University Hospital of Asturias (HUCA), Oviedo, Spain \\ ${ }^{4}$ Laboratory of Structural Biology and Proteomics, University of Veterinary and Pharmaceutical Sciences, Brno, Czech Republic \\ ${ }^{5}$ Department of Functional Sciences, Discipline of Pathophysiology, "Victor Babes" University of Medicine and Pharmacy, Timisoara, \\ Romania
}

\section{Correspondence:}

Peter Kruzliak, Laboratory of Structural Biology and Proteomics, University of Veterinary and Pharmaceutical Sciences, Brno, Czech Republic E-mail: peter.kruzliak@savba.sk Tel: +420543181111

Received: 12 Dec 2016 Accepted: 21 Dec 2016 Published Online: 19 May 2017 Published: 29 Sep 2017

Key words: glycemic variability, MAGE index, diabetes mellitus complications

Citation: Caprnda M, Mesarosova D, Ortega PF, Krahulec B, Egom E, Rodrigo L, Kruzliak P, Mozos I, Gaspar L. Glycemic variability and vascular complications in patients with type 2 diabetes mellitus.

Folia Medica 2017;59(3):270-278. doi: 10.1515/folmed-2017-0048
Background: Presence of macro- and microvascular complications in patients with diabetes mellitus (DM) is not only related to chronic hyperglycemia represented by glycated hemoglobin ( $\mathrm{HbA} 1 \mathrm{c})$ but also to acute glycemic fluctuations (glycemic variability, GV). The association between GV and DM complications is not completely clear. Aim of our study was to evaluate GV by MAGE index in patients with type 2 DM and to verify association of MAGE index with presence of macro- and microvascular DM complications.

Methods: 99 patients with type 2 DM were included in the study. Every patient had done big glycemic profile, from which MAGE index was calculated. Anthropometric measurements, evaluation of $\mathrm{HbA} 1 \mathrm{c}$ and fasting plasma glucose (FPG) and assessment for macrovascular (coronary artery disease - CAD; peripheral artery disease PAD; cerebral stroke - CS) and microvascular (diabetic retinopathy - DR; nephropathy - DN; peripheral neuropathy - DPPN) DM complications were done.

Results: Average MAGE index value was $5.15 \pm 2.88 \mathrm{mmol} / \mathrm{l}$. We found no significant differences in MAGE index values in subgroups according to presence of neither $C A D, C S, P A D$ nor DR, DN, DPPN. MAGE index value significantly positively correlated with FPG $(p<0.01)$ and HbA1c $(p<0.001)$ and negatively with weight $(p<0.05)$.

Conclusion: In our study we failed to show association of MAGE index with presence of macrovascular and microvascular complications in patients with type $2 \mathrm{DM}$. However, this negative result does not necessarily disprove importance of glycemic variability in pathogenesis of diabetic complications.

\section{BACKGROUND}

Diabetes mellitus (DM) is a metabolic disease accompanied by development of specific micro- and macrovascular complications. Presence of both complications depends mostly on disorder of glucose levels, which has two main components: long-term chronic hyperglycemia (both fasting and postprandial) and acute glycemic fluctuations between high and low values (glycemic variability). ${ }^{1}$ All those components lead to diabetic complications through two main mechanisms: increased glycation of proteins and activation of oxidative stress. Glycated hemoglobin $(\mathrm{HbA} 1 \mathrm{c})$ is the main marker of fasting and postprandial hyperglycemia and its level posi- tively correlates with presence of both macro- and microvascular diabetic complications. ${ }^{2,3}$ On the other hand, many authors suggested, that glycemic variability could be also an independent risk factor for development of diabetic complications. $4,5,6,7$

Measurement of glycemic variability can be realized by various calculations. The most simple is standard deviation (SD) calculated of all measured glucose levels. Another method is called MAGE index (Mean Amplitude of Glycemic excursions), calculated as arithmetic mean of differences between those glucose measurements, which are higher than 1 SD. ${ }^{8}$ Other methods of glycemic variability calculations are shown in review articles by Hill. ${ }^{9}$ 
and Martinka. ${ }^{10}$

Good reproducibility of glycemic variability measurement requires standardization of both calculation of glycemic variability and glucose level measurements. Glucose levels can be measured repeatedly during one day (within-day glucose variability) or during more days (between-day glucose variability). ${ }^{11}$ Other method is continual measurement of glucose levels by Continual Glucose Monitoring System (CGMS). ${ }^{12}$

The rationale for glycemic variability measurement was studied by many authors. ${ }^{4,5,6,7}$ Glucose levels fluctuations had negative impact on function of pancreatic beta-cells, renal mesangial and tubulointerstitial cells and endothelial cells. ${ }^{13}$ Increased value of glycemic variability evaluated by MAGE index correlated with increased excretion of 8-oxo-prostaglandine F2-alpha, which is considered a marker of oxidative stress in patients with DM. ${ }^{14,15,16}$, but other study did not support this findings. ${ }^{17}$ Importance of glycemic variability monitoring was ambiguous in clinical studies and was different in patients with type 1 and type 2 DM. ${ }^{6}$ Data analysis from Diabetes Control and Complications Trial (DCCT), which included 7 measurements of glucose level during one day, did not show relationship of glycemic variability evaluated by SD or MAGE index to presence of microvascular complications ${ }^{18}$, neither peripheral nor autonomic neuropathy. ${ }^{19}$ However, in type 2 DM patients, increased values of MAGE index were associated with presence of coronary artery disease. $^{20}$ Increased glycemic variability was associated with total and cardiovascular mortality in patients older than 75 years. ${ }^{21,22}$ These results in type $2 \mathrm{DM}$ patients were confirmed by another study. ${ }^{23}$ Glycemic variability was also responsible for development of diabetic retinopathy ${ }^{24,25}$, but this was not confirmed by another study. ${ }^{26}$ However, possible explanation for presented differences between the studies could be different methods of glycemic variability evaluation.

\section{AIM OF THE STUDY}

Primary aim of the presented study was to analyze glycemic variability by MAGE index in hospitalized patients with type 2 diabetes mellitus, who underwent complex examination by diabetologist and evaluate the association of glycemic variability to presence of diabetic macro- and microvascular complications. Secondary goal was to evaluate impact of DM treatment on glycemic variability.

\section{MATERIAL AND METHODS}

Patients included in the study were hospitalized at $2^{\text {nd }}$ Department of Internal Medicine, University Hospital Bratislava between January 2012 and October 2013 and during hospitalization sent to complex examination by diabetologist. Every included patient underwent within-day glucose measurement ("glycemic profile"), which consisted of 7 values of glucose measured from capillary blood by local biochemistry lab. Glucose levels were measured 10 minutes before and 90 minutes after main meals (breakfast, lunch and dinner) and at 3:00am in the night. Glycemic variability was calculated by MAGE index according to equation by Service et al. ${ }^{8}$

Every patient underwent basic anthropometric measurements (height, weight and waist circumference), from which body mass index (BMI) was calculated. Pathologic values for BMI were 25-30 $\mathrm{kg} / \mathrm{m}^{2}$ (overweight patients) and $>30 \mathrm{~kg} / \mathrm{m}^{2}$ (obese patients ${ }^{27}$; pathologic values for waist circumference were chosen according to International Diabetes Federation: men $>94 \mathrm{~cm}$, women $>80 \mathrm{~cm} .{ }^{28}$ Patients had also measured fasting plasma glucose from venous blood (FPG) and glycated hemoglobin (HbAlc) by method according to International Federation of Clinical Chemistry (IFCC). In those patients, who had HbAlc measured by Diabetes Control and Complications Trial (DCCT) method, we used transformation equation. ${ }^{29}$; results are presented by both methods. Good metabolic compensation was in patients with $\mathrm{HbAlc}<53 \mathrm{mmol} / \mathrm{mol}$ (IFCC) or $<$ $7.0 \%$ (DCCT) respectively. ${ }^{30}$ Treatment of diabetes mellitus in study patients was also evaluated (diet alone, oral antidiabetic drugs - OAD, insulin).

Presence of macrovascular complications - coronary artery disease (CAD), myocardial infarction (MI), cerebral stroke (CS) and peripheral artery disease (PAD) was evaluated by history taking and confirmed by patients' documentation. Presence of PAD was also evaluated by measurement of anklebrachial pressure index (ABI); diagnostic criterion for $\mathrm{PAD}$ was $\mathrm{ABI}<0.90{ }^{31}$

Of microvascular complications we evaluated retinopathy, nephropathy and peripheral neuropathy. Presence of diabetic retinopathy was evaluated by funduscopy by ophthalmologist or by history taking. Diabetic nephropathy (chronic kidney disease, CKD) was evaluated by presence of decrease estimated glomerular filtration rate (eGFR) calculated by Modification of Diet in Renal Disease study (MDRD) equation $<60 \mathrm{ml} / \mathrm{min} / 1.73 \mathrm{~m}^{2} .{ }^{32}$ and/or excretion ratio of albumin and creatinine (ACR) 
$>3 \mathrm{mg} / \mathrm{mmol} .{ }^{33}$ Peripheral sensory diabetic neuropathy was assessed by evaluation of peripheral sensitivity: light touch, pinprick and warm-cold difference sensation, examination with SemmesWeinstein $10 \mathrm{~g}$ monofilament, vibratory sense by biothesiometer and patellar and Achilles tendon reflexes ${ }^{34}$; of those measurements, Neuropathy Symptoms Score (NSS) and Neuropathy Disability Score (NDS) were calculated after Young. ${ }^{35}$

Acquired data were entered into Microsoft Excel database and statistical analysis was performed by IBM SPSS for Windows. Numeric data with normal distribution were described by arithmetic mean and standard deviation (SD). To analyze statistical relationship between categorical variables we used chi-square test, to compare continuous data between two groups we used unpaired Student's t-test, comparison between more than 2 groups was done by analysis of variance (ANOVA) test. Strength of association between 2 parametric variables was evaluated by Pearson's correlation analysis. Significance level for all statistical tests was set below 0.05 .

\section{RESULTS}

Basic information about the patients is shown in Table 1. There were 99 patients (46 men, 53 women) included in the study, aged 32-91 years (mean age $69.59 \pm 12.29$ years). Duration of diabetes mellitus was $0-50$ years (mean duration $15.76 \pm 11.83$ years). Mean fasting plasma glucose was $11.60 \pm$ $5.51 \mathrm{mmol} / \mathrm{l}$, mean level of glycated hemoglobin

Table 1. Basic history, biochemical and anthropometric parameters

\begin{tabular}{|c|c|c|c|c|}
\hline Parameter & $\begin{array}{l}\text { All patients } \\
(\mathrm{n}=99)\end{array}$ & $\begin{array}{c}\text { Men } \\
(n=46)\end{array}$ & $\begin{array}{l}\text { Women } \\
(\mathrm{n}=53)\end{array}$ & $\begin{array}{c}\text { Significance } \\
\text { men vs. women }\end{array}$ \\
\hline Age [years] & $69.59 \pm 12.29$ & $67.09 \pm 12.37$ & $71.75 \pm 11.92$ & NS \\
\hline Duration of DM [years] & $15.76 \pm 11.83$ & $15.40 \pm 12.98$ & $16.06 \pm 10.89$ & NS \\
\hline $\mathrm{FPG}[\mathrm{mmol} / \mathrm{l}]$ & $11.60 \pm 5.51$ & $11.65 \pm 5.16$ & $11.55 \pm 5.90$ & NS \\
\hline $\begin{array}{l}\mathrm{HbAlc}(\mathrm{IFCC})[\mathrm{mmol} / \mathrm{mol}] \\
\mathrm{HbAlc}(\mathrm{DCCT})[\%]\end{array}$ & $\begin{aligned} 75.40 & \pm 27.71 \\
9.05 & \pm 2.54\end{aligned}$ & $\begin{aligned} 74.06 & \pm 26.33 \\
8.93 & \pm 2.41\end{aligned}$ & $\begin{aligned} 76.56 & \pm 29.05 \\
9.15 & \pm 2.66\end{aligned}$ & NS \\
\hline $\mathrm{HbA} 1 \mathrm{c}(\mathrm{IFCC})<53 \mathrm{mmol} / \mathrm{mol}[\%]$ & $22.7 \%$ & $24.4 \%$ & $21.2 \%$ & NS \\
\hline MAGE index $[\mathrm{mmol} / 1]$ & $5.15 \pm 2.88$ & $4.81 \pm 2.33$ & $5.45 \pm 3.28$ & NS \\
\hline BMI $\left[\mathrm{kg} / \mathrm{m}^{2}\right]$ & $31.38 \pm 6.56$ & $30.08 \pm 6.89$ & $32.40 \pm 6.19$ & NS \\
\hline BMI $18-25 \mathrm{~kg} / \mathrm{m}^{2}$ & $18.3 \%$ & $19.4 \%$ & $17.5 \%$ & \\
\hline BMI $25-30 \mathrm{~kg} / \mathrm{m}^{2}$ & $29.6 \%$ & $45.2 \%$ & $17.5 \%$ & $\mathrm{p}<0.05$ \\
\hline $\mathrm{BMI}>30 \mathrm{~kg} / \mathrm{m}^{2}$ & $52.1 \%$ & $35.5 \%$ & $65.0 \%$ & \\
\hline $\mathrm{WC}[\mathrm{cm}]$ & $109.75 \pm 13.35$ & $107.35 \pm 13.77$ & $111.26 \pm 13.11$ & NS \\
\hline $\begin{array}{l}\mathrm{WC}>80 \mathrm{~cm} \text { (women) } \\
\mathrm{WC}>94 \mathrm{~cm} \text { (men) }\end{array}$ & $93.2 \%$ & $88.2 \%$ & $96.3 \%$ & NS \\
\hline
\end{tabular}

Table 2. Basic information about treatment of diabetes mellitus

\begin{tabular}{lcccc}
\hline \multicolumn{1}{c}{ Parameter } & $\begin{array}{c}\text { All patients } \\
(\mathbf{n = 9 9 )}\end{array}$ & $\begin{array}{c}\text { Men } \\
(\mathbf{n = 4 6 )}\end{array}$ & $\begin{array}{c}\text { Women } \\
(\mathbf{n}=\mathbf{5 3})\end{array}$ & $\begin{array}{c}\text { Significance } \\
\text { men vs. women }\end{array}$ \\
\hline Diet only & $8.1 \%$ & $4.3 \%$ & $11.3 \%$ & \\
Oral antidiabetic drugs & $25.3 \%$ & $32.6 \%$ & $18.9 \%$ & $\mathrm{NS}$ \\
Insulin & $39.4 \%$ & $41.3 \%$ & $37.7 \%$ & \\
Oral antidiabetic drugs + insulin & $27.3 \%$ & $21.7 \%$ & $32.1 \%$ & \\
\hline
\end{tabular}


according to IFCC was $75.40 \pm 27.71 \mathrm{mmol} / \mathrm{mol}$ (according to DCCT $9.05 \% \pm 2.54 \%$ ). Mean BMI value was $31.38 \pm 6.56 \mathrm{~kg} / \mathrm{m}^{2}$; in men was lower prevalence of obesity (BMI $>30 \mathrm{~kg} / \mathrm{m}^{2}$ ) compared to women $(35.5 \%$ vs. $65.0 \%$; $<<0.05)$. Mean waist circumference was $107.35 \pm 13.77 \mathrm{~cm}$ in men and $111.26 \pm 13.11 \mathrm{~cm}$ in women; $93.2 \%$ of subjects had higher waist circumference than recommended values by IDF. $^{28}$

Table 2 describes the treatment of diabetes mellitus in study patients. There were 8 patients treated by diet alone $(8.1 \%), 25$ patients treated by OAD $(25.3 \%), 39$ patients treated by insulin (39.4\%) and 27 patients treated by combination of OAD and insulin (27.3\%).

Prevalence of macrovascular and microvascular diabetic complications is shown in Table 3. History of CAD was present in $59.8 \%$ patients and 18.8 $\%$ was after myocardial infarction. Prevalence of cerebral stroke was $27.1 \%$ and peripheral artery disease $27.8 \%$. Most common microvascular complication was peripheral diabetic polyneuropathy in $87.9 \%$ of patients and nephropathy in $67.1 \%$ of patients.

Fig. 1 and Fig. 2 show mean values of MAGE index according to presence or absence of macroand microvascular diabetic complications. There were no significant differences in glycemic variability represented by MAGE index between presented subgroups.

Correlation analysis was performed between MAGE index and patients' age, duration of DM,

Table 3. Prevalence of macrovascular and microvascular diabetic complications

\begin{tabular}{lcccc}
\hline \multicolumn{1}{c}{ Parameter } & $\begin{array}{c}\text { All patients } \\
(\mathbf{n = 9 9 )}\end{array}$ & $\begin{array}{c}\text { Men } \\
(\mathbf{n = 4 6 )}\end{array}$ & $\begin{array}{c}\text { Women } \\
(\mathbf{n = 5 3 )}\end{array}$ & $\begin{array}{c}\text { Significance } \\
\text { men vs. women }\end{array}$ \\
\hline Coronary artery disease & $58.8 \%$ & $48.9 \%$ & $67.3 \%$ & $\mathrm{NS}$ \\
Myocardial infarction & $18.8 \%$ & $15.6 \%$ & $21.6 \%$ & $\mathrm{NS}$ \\
Cerebral stroke & $27.1 \%$ & $35.6 \%$ & $19.6 \%$ & $\mathrm{NS}$ \\
Peripheral artery disease & $26.3 \%$ & $35.6 \%$ & $18.0 \%$ & $\mathrm{NS}$ \\
Diabetic retinopathy & $38.2 \%$ & $32.4 \%$ & $44.1 \%$ & $\mathrm{NS}$ \\
Diabetic nephropathy & $67.1 \%$ & $57.1 \%$ & $77.1 \%$ & $\mathrm{NS}$ \\
Diabetic peripheral polyneuropathy & $87.9 \%$ & $91.3 \%$ & $84.9 \%$ & $\mathrm{NS}$ \\
\hline
\end{tabular}

Table 4. Correlation analysis between MAGE index and patients' age, duration of diabetes mellitus, fasting plasma glucose (FPG), glycated hemoglobin (HbA1c)

\begin{tabular}{ccccc}
\hline & Age & Duration of DM & FPG & HbA1c \\
\hline \multirow{2}{*}{ MAGE index } & $\mathrm{r}=+0.116$ & $\mathrm{r}=+0.139$ & $\mathrm{r}=+0.359$ & $\mathrm{r}=+0.339$ \\
& $\mathrm{NS}$ & $\mathrm{NS}$ & $\mathrm{p}<0.01$ & $\mathrm{p}<0.001$ \\
\hline
\end{tabular}

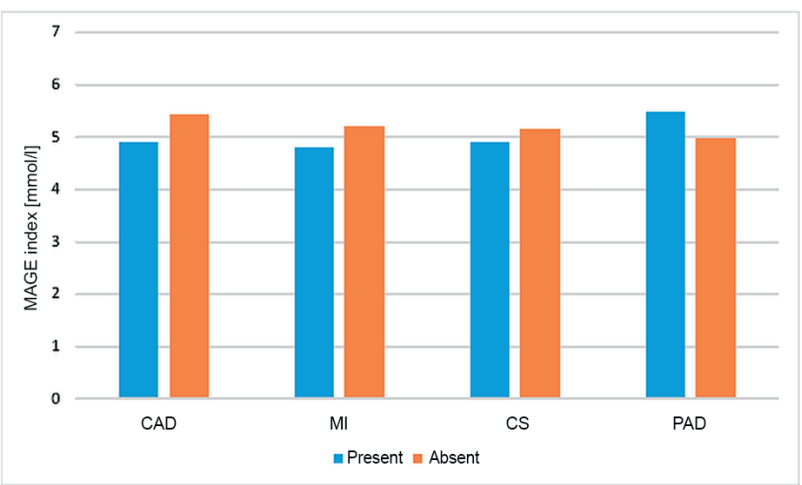

Figure 1. Mean values of MAGE index according to presence or absence of macrovascular diabetic complications. CAD - coronary artery disease, $\mathrm{MI}$ - myocardial infarction, $\mathrm{CS}$ - cerebral stroke, PAD - peripheral artery disease.

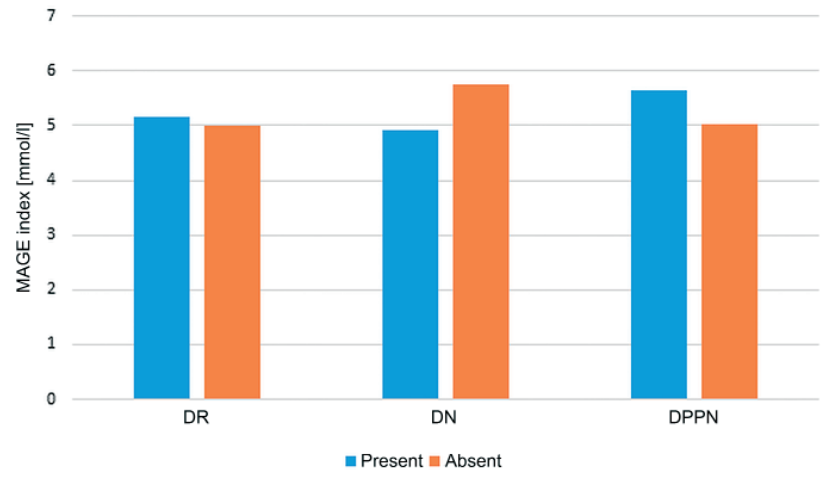

Figure 2. Mean values of MAGE index according to presence or absence of microvascular diabetic complications. DR - diabetic retinopathy, DN - diabetic nephropathy, DPPN - diabetic peripheral polyneuropathy. 
Table 5. Correlation analysis between weight, body mass index (BMI), waist circumference (WC) and MAGE index, fasting plasma glucose (FPG), glycated hemoglobin (HbA1c)

\begin{tabular}{lccc}
\hline & Weight & BMI & WC \\
\hline MAGE index & $\mathrm{r}=-0.246$ & $\mathrm{r}=-0.184$ & $\mathrm{r}=-0.243$ \\
& $\mathrm{p}<0.05$ & $\mathrm{NS}(\mathrm{p}=0.12)$ & $\mathrm{NS}(\mathrm{p}=0.11)$ \\
FPG & $\mathrm{r}=+0.275$ & $\mathrm{r}=+0.233$ & $\mathrm{r}=+0.134$ \\
& $\mathrm{p}<0.05$ & $\mathrm{NS}(\mathrm{p}=0.09)$ & $\mathrm{NS}$ \\
HbA1c & $\mathrm{r}=+0.288$ & $\mathrm{r}=+0.324$ & $\mathrm{r}=+0.117$ \\
& $\mathrm{p}<0.05$ & $\mathrm{p}<0.01$ & $\mathrm{NS}$ \\
\hline
\end{tabular}

Table 6. Mean values of fasting plasma glucose (FPG), glycated hemoglobin (HbA1c), diabetes compensation and MAGE index according to diabetes therapy subgroups

\begin{tabular}{lccccc}
\hline \multicolumn{1}{c}{ Therapy of DM } & $\begin{array}{c}\text { Diet only } \\
(\mathbf{n}=\mathbf{8})\end{array}$ & $\begin{array}{c}\text { OAD only } \\
(\mathbf{n}=\mathbf{2 5})\end{array}$ & $\begin{array}{c}\text { Insulin only } \\
(\mathbf{n}=\mathbf{3 9})\end{array}$ & $\begin{array}{c}\text { OAD }+ \text { in- } \\
\text { sulin } \\
(\mathbf{n}=\mathbf{2 7})\end{array}$ & $\begin{array}{c}\text { Signifi- } \\
\text { cance }\end{array}$ \\
\hline FPG [mmol/l] & $15.35 \pm 5.90$ & $9.23 \pm 4.11$ & $11.94 \pm 5.61$ & $11.44 \pm 5.69$ & $\mathrm{NS}$ \\
$\mathrm{HbAlc}(\mathrm{IFCC})[\mathrm{mmol} / \mathrm{mol}]$ & $103.64 \pm 38.43$ & $69.31 \pm 24.32$ & $71.41 \pm 27.63$ & $78.40 \pm 22.60$ & $\mathrm{p}<0.05$ \\
$\mathrm{HbAlc}(\mathrm{DCCT})[\%]$ & $11.63 \pm 3.52$ & $8.49 \pm 2.23$ & $8.86 \pm 2.53$ & $9.32 \pm 2.07$ & \\
$\mathrm{HbAlc}(\mathrm{IFCC})<53 \mathrm{mmol} / \mathrm{mol}[\%]$ & $0.0 \%$ & $36.0 \%$ & $28.9 \%$ & $7.7 \%$ & $\mathrm{p}<0.05$ \\
MAGE index $[\mathrm{mmol} / \mathrm{l}]$ & $5.38 \pm 4.02$ & $5.18 \pm 2.26$ & $5.17 \pm 3.12$ & $5.03 \pm 2.83$ & $\mathrm{NS}$ \\
\hline
\end{tabular}

weight, BMI, waist circumference, fasting plasma glucose and glycated hemoglobin. We found significant moderate positive correlations between MAGE index and FPG $(\mathrm{r}=+0.359 ; \mathrm{p}<0.01)$, MAGE index and HbAlc $(r=+0.339 ; \mathrm{p}<0.001)$ and weak but significant negative correlation between MAGE index and weight $(\mathrm{r}=-0.246 ; \mathrm{p}<0.05)$. No significant correlation was found between MAGE index and BMI, age and duration of DM (Tables 4, 5). There was also significant positive correlation between FPG and $\mathrm{HbA} 1 \mathrm{c}$ and weight and BMI (Table 5).

Mean values of MAGE index, fasting plasma glucose, glycated hemoglobin and percentage of well compensated diabetics in patients' subgroups according to therapy of diabetes mellitus are shown in Table 6. We found no significant association between MAGE index and type of therapy. There was significant difference in mean $\mathrm{HbAlc}$ values between therapy groups $(p<0.05)$, mostly due to higher $\mathrm{HbA} 1 \mathrm{c}$ values in patients treated by diet only. Similar differences were observed for percentages of good compensation of DM ( $p<0.05)$, but not for mean FPG values.

\section{DISCUSSION}

Chronic metabolic compensation of plasma glucose represented by glycated hemoglobin does not reflect daily glycemic variations, which increase oxidative stress in diabetic patients and contribute to formation of diabetic complications. Patients with similar values of glycated hemoglobin can have markedly different glycemic values during the day. Monitoring of glycemic profile or continual monitoring of glycemia gives about changes of plasma glucose during the day and adds more information about glycemic dysbalance together with $\mathrm{HbAlc}$. This is also supported by presence of significant correlation of $\mathrm{HbA} 1 \mathrm{c}$ with glycemic variability represented by MAGE index $(\mathrm{r}=+0,339 ; \mathrm{p}<0,001)$; this was also observed by other authors. . $^{36,37,38}$

Average value of MAGE index in presented study was $5.15 \pm 2.88 \mathrm{mmol} / \mathrm{l}$; this is markedly more, than $2.8 \mathrm{mmol} / 1$, the highest recommended value in healthy subjects by. ${ }^{9}$ Value below $2.8 \mathrm{mmol} / 1$ was achieved in our study only by $23.3 \%$ of patients. However, other authors recommend different upper limit values for MAGE index: Monnier et al recommended even lower normal value $40 \mathrm{mg} / \mathrm{dl}$, 
which corresponds approximately to $2.22 \mathrm{mmol} / \mathrm{l}^{1}$ On the other hand, newer study of Chinese authors $\mathrm{Su}, \mathrm{Mi}$, Tao et al suggested MAGE index $>3.4$ $\mathrm{mmol} / \mathrm{l}$ as independent predictor for incidence of coronary heart disease. ${ }^{20}$ The same group of authors used discrimination value of $3.9 \mathrm{mmol} / 1$ to compare incidence of cardiovascular events in patients after acute myocardial infarction. ${ }^{39}$

Values of MAGE index were not significantly different between subgroups of patients according to treatment; there was a minor trend to higher values of MAGE index in patients without any treatment, which could be attributed to presence of newly diagnosed diabetic patients who were present in the study (this could also explain higher levels of HbA1c and glycemia in this subgroup). Other authors found decreased glycemic variability in patients treated by oral antidiabetic drugs. ${ }^{38,40}$ HEART2D study, which compared effects of basal and prandial insulin treatment on incidence of cardiovascular events, found lower glycemic variability in patients with prandial insulin treatment, however, this was not reflected in decrease of cardiovascular events. ${ }^{41}$ Some authors showed positive effect of DPP-4 inhibitors (gliptins), especially vildagliptin, on lowering glycemic variability. ${ }^{42,43,44}$; in our study we could not evaluate effect of gliptins on MAGE index, because only 6 patients were treated by gliptins: 3 patients were treated by sitagliptin and 3 patients by vildagliptin.

Correlation analysis of MAGE index with anthropometric parameters showed significant negative correlation of MAGE index and body weight, while BMI and waist circumference showed only a trend to negative correlation with MAGE index. This finding was also present in study of Romanian authors Gribovschi et al. ${ }^{38}$ On the contrary, fasting plasma glucose and $\mathrm{HbAlc}$ positively correlated with weight and BMI, which underlines importance of obesity in long-term compensation of diabetes mellitus. We haven't found significant correlation neither between MAGE index and age nor duration of diabetes mellitus, which was described in study by Gribovschi et al. ${ }^{38}$

Analysis of MAGE index values according to presence or absence of macrovascular (Fig. 1) or microvascular (Fig. 2) complications of diabetes mellitus has not found any significant differences between subgroups. As it was stated above, some of the published studies did confirm relationship of glycemic variability in patients with type 2 diabetes mellitus to presence of macrovascular. ${ }^{20-23,39}$ and microvascular complications of diabetes mellitus. ${ }^{24,25}$ However, majority of those studies were using continuous glucose monitoring system (CGMS) to calculate glycemic variability, while in our study we employed standard method common in our practice - measurement of within-day glycemic profile consisting of 7 values. Similar method was also used in analysis of glycemic variability in DCCT study in type 1 diabetes mellitus patients, which did not confirm association of MAGE index with presence of diabetic complications. ${ }^{18,19}$ Hirsch and Brownlee wrote, that evaluation of glycemic variability can be significantly underrated without continual glucose monitoring; ${ }^{45}$ however, in our study majority of patients had higher MAGE index value than recommended $2.8 \mathrm{mmol} / \mathrm{l}$ by Hill et al. ${ }^{9}$ If CGMS in future becomes widely available in diagnostics and monitoring of treatment of patients with diabetes mellitus, such as 24-hour blood pressure and ECG monitoring, more precise analysis of glycemic variability can become an important tool to assess risk of diabetic complications. ${ }^{12}$

\section{CONCLUSION}

In our study we failed to show association of glycemic variability assessed by MAGE index calculated from within-day seven values of plasma glucose with presence of macrovascular and microvascular complications in hospitalized patients with type 2 DM. However, this negative result does not necessarily disprove importance of glycemic variability in pathogenesis of diabetic complications. Further studies with better analysis of glycemic variability, such as continuous glucose monitoring system, are needed in future.

\section{LIMITATIONS}

The method we used to measure within-day glycemic profile consisted of 7 samples over the course of a day might explain the negative results they obtain compared to other studies that used continuous glucose monitoring. In addition, the sample size of 99 patients might also contribute that hardly any statistical significant correlations were found.

\section{CONFLICT OF INTEREST}

Authors declare no conflict of interest.

\section{REFERENCES}

1. Monnier L, Colette C. Glycemic variability:should we and can we prevent it? Diabetes Care 2008;31(Suppl 2):S150-4. 
2. The relationship of glycemic exposure (HbAlc) to the risk of development and progression of retinopathy in the diabetes control and complications trial. Diabetes 1995;44(8):968-83.

3. UK Prospective Diabetes Study (UKPDS) Group. Intensive blood-glucose control with sulphonylureas or insulin compared with conventional treatment and risk of complications in patients with type 2 diabetes (UKPDS 33). Lancet 1998;352(9131):837-53.

4. Ceriello A, Kilpatrick ES. Glycemic variability:both sides of the story. Diabetes Care 2013;36(Suppl. 2): 272-5.

5. Kilpatrick ES. Arguments for and against the role of glucose variability in the development of diabetes complications. J Diabetes Sci Technol 2009;3(4):649-55.

6. Nalysnyk L., Hernandez-Medina M., Krishnarajah G. Glycaemic variability and complications in patients with diabetes mellitus:evidence from a systematic review of the literature. Diabetes Obes Metab 2010;12(4):288-98.

7. Siegelaar SE, Holleman F, Hoekstra JB, et al. Glucose variability; does it matter? Endocr Rev 2010;31(2):171-82.

8. Service FJ, Molnar GD, Rosevear JW, et al. Mean amplitude of glycemic excursions, a measure of diabetic instability. Diabetes 1970;19(9):644-55.

9. Hill NR, Oliver NS, Choudhary P, et al. Normal reference range for mean tissue glucose and glycemic variability derived from continuous glucose monitoring for subjects without diabetes in different ethnic groups. Diabetes Technol Ther 2011;13(9):921-8.

10. Martinka E. Glycemic variability:how important is its evaluation in clinical practice? Forum Diabetologicum 2013;2(2):127-9.

11. Tylee TS, Trence DL. Glycemic Variability:Looking Beyond the A1C. Diabetes Spectrum 2012;25(3): 149-53.

12. Bendžala M, Krahulec B, Sabaka P, et al. Continuous glucose concentration monitoring. Forum Diabetologicum 2012;1(2-3):92-5.

13. Ceriello A, Ihnat MA. 'Glycaemic variability':a new therapeutic challenge in diabetes and the critical care setting. Diabet Med 2010;27(8):862-7.

14. Ceriello A, Esposito K, Piconi L, et al. Oscillating glucose is more deleterious to endothelial function and oxidative stress than mean glucose in normal and type 2 diabetic patients. Diabetes 2008;57(5):1349-54.

15. Di Flaviani A, Picconi F, Di Stefano P, et al. Impact of glycemic and blood pressure variability on surrogate measures of cardiovascular outcomes in type 2 diabetic patients. Diabetes Care 2011;34(7):1605-9.

16. Monnier L, Mas E, Ginet C, et al. Activation of oxidative stress by acute glucose fluctuations compared with sustained chronic hyperglycemia in patients with type 2 diabetes. JAMA 2006;295(14):1681-7.

17. Wentholt IM, Kulik W, Michels RP, et al. Glucose fluctuations and activation of oxidative stress in patients with type 1 diabetes. Diabetologia 2008;51(1):183-90.

18. Kilpatrick ES, Rigby AS, Atkin SL. Effect of glucose variability on the long-term risk of microvascular complications in type 1 diabetes. Diabetes Care 2009;32(10):1901-3.

19. Siegelaar SE, Kilpatrick ES, Rigby AS, et al. Glucose variability does not contribute to the development of peripheral and autonomic neuropathy in type 1 diabetes:data from the DCCT. Diabetologia 2009;52(10):2229-32.

20. Su G, Mi SH, Tao H, et al. Association of glycemic variability and the presence and severity of coronary artery disease in patients with type 2 diabetes. Cardiovasc Diabetol 2011;10:19.

21. Muggeo M, Verlato G, Bonora E, et al. Long-term instability of fasting plasma glucose predicts mortality in elderly NIDDM patients:the Verona Diabetes Study. Diabetologia 1995;38(6):672-9.

22. Muggeo M, Verlato G, Bonora E, et al. Long-term instability of fasting plasma glucose, a novel predictor of cardiovascular mortality in elderly patients with non-insulin-dependent diabetes mellitus:the Verona Diabetes Study. Circulation 1997;96(6):1750-4.

23. Lin CC, Li CI, Yang SY, et al. Variation of fasting plasma glucose:a predictor of mortality in patients with type 2 diabetes. Am J Med 2012;125(4):416. e9-18.

24. Gimeno-Orna JA, Castro-Alonso FJ, Boned-Juliani $\mathrm{B}$, et al. Fasting plasma glucose variability as a risk factor of retinopathy in Type 2 diabetic patients. $\mathrm{J}$ Diabetes Complications 2003;17(2):78-81.

25. Takao T, Ide T, Yanagisawa H, et al. The effect of fasting plasma glucose variability on the risk of retinopathy in type 2 diabetic patients:retrospective long-term follow-up. Diabetes Res Clin Pract 2010;89(3):296-302.

26.Zoppini G, Verlato G, Targher G, et al. Is fasting glucose variability a risk factor for retinopathy in people with type 2 diabetes? Nutr Metab Cardiovasc Dis 2009;19(5):334-9.

27. World Health Organization. Report of a WHO consultation on obesity. Obesity:preventing and managing the global epidemic. Geneva, World Health Organization, 1998.

28. Alberti KG, Zimmet P, Shaw J, et al. The metabolic syndrome - a new worldwide definition. Lancet 2005;366(9491):1059-62.

29. Consensus statement on the worldwide standardization of the hemoglobin A1C measurement:the American Diabetes Association, European Association for 
the Study of Diabetes, International Federation of Clinical Chemistry and Laboratory Medicine, and the International Diabetes Federation. Diabetes Care 2007;30(9):2399-400.

30. Rydén L, Grant PJ, Anker SD, et al. ESC Guidelines on diabetes, pre-diabetes, and cardiovascular diseases developed in collaboration with the EASD:the Task Force on diabetes, pre-diabetes, and cardiovascular diseases of the European Society of Cardiology (ESC) and developed in collaboration with the European Association for the Study of Diabetes (EASD). Eur Heart J 2013;34(39):3035-87.

31. Norgren L, Hiatt WR, Dormandy JA, et al. Intersociety consensus for the management of peripheral arterial disease. Int Angiol 2007;26(2):81-157.

32. Levey AS, Bosch JP, Lewis JB, et al. A more accurate accurate method to estimate glomerular filtration rate from serum creatinine:a new prediction equation. Modification of Diet in Renal Disease Study Group. Ann Intern Med 1999;130(6):461-70.

33. KDIGO Clinical Practice Guideline for the Evaluation and Management of Chronic Kidney Disease. Chapter 1:Definition and classification of CKD. Kidney Inter Suppl 2013;3(1):19-62.

34. Krahulec B, Štrbová L. Základy podiatrie. In:Krahulec B, Gašpar L', Štvrtinová V, et al. Manažment pacienta so syndrómom diabetickej nohy. Bratislava, VEDA, 2013;64-83.

35. Young MJ, Boulton AJ, MacLeod AF, et al. A multicentre study of the prevalence of diabetic peripheral neuropathy in the United Kingdom hospital clinic population. Diabetologia 1993;36(2):150-4.

36. Bode BW, Gross TM, Thornton KR, et al. Continuous glucose monitoring used to adjust diabetes therapy improves glycosylated hemoglobin:a pilot study. Diabetes Res Clin Pract 1999;46(3):183-90.

37. Bonora E, Calcaterra F, Lombardi S, et al. Plasma glucose levels throughout the day and $\mathrm{HbA}(1 \mathrm{c})$ interrelationships in type 2 diabetes:implications for treatment and monitoring of metabolic control. Diabetes Care 2001;24(12):2023-9.

38. Gribovschi M, Ţigan Ş, Hâncu N. Glycemic Variability and Type 2 Diabetes Mellitus. Appl Med Inform 2013;32(1), 53-60.

39. Su G, Mi SH, Tao H, et al. Impact of admission glycemic variability, glucose, and glycosylated hemoglobin on major adverse cardiac events after acute myocardial infarction. Diabetes Care 2013;36(4):1026-32.

40. Monnier L, Colette C, Mas E, et al. Regulation of oxidative stress by glycaemic control:evidence for an independent inhibitory effect of insulin therapy. Diabetologia 2010;53(3):562-71.

41. Siegelaar SE, Kerr L, Jacober SJ, et al. A decrease in glucose variability does not reduce cardiovascular event rates in type 2 diabetic patients after acute myocardial infarction:a reanalysis of the HEART2D study. Diabetes Care 2011;34(4):855-7.

42. Barbieri M, Rizzo MR, Marfella R, et al. Decreased carotid atherosclerotic process by control of daily acute glucose fluctuations in diabetic patients treated by DPP-IV inhibitors. Atherosclerosis 2013;227(2):349-54.

43. Guerci B, Monnier L, Serusclat P, et al. Continuous glucose profiles with vildagliptin versus sitagliptin in add-on to metformin:results from the randomized Optima study. Diabetes Metab 2012;38(4):359-66.

44. Rizzo MR, Barbieri M, Marfella R, et al. Reduction of oxidative stress and inflammation by blunting daily acute glucose fluctuations in patients with type 2 diabetes:role of dipeptidyl peptidase-IV inhibition. Diabetes Care 2012;35(10):2076-82.

45. Hirsch IB, Brownlee M. Beyond hemoglobin A $1 \mathrm{c}$ - need for additional markers of risk for diabetic microvascular complications. JAMA 2010;303(22):2291-2. 


\section{Вариабельность уровня глюкозы и микрососудистые осложнения у пациентов с сахарным диабетом 2-ого типа}

\section{Мартин Капрнда ${ }^{1}$, Даса Месаросова ${ }^{1}$, Пабло Фабуел Ортега ${ }^{1}$, Брис Крахулец ${ }^{1}$, Емануел Егом$^{2}$, Луис Родриго ${ }^{3}$, Петер Крузлиак ${ }^{4}$, Йоана Мозос ${ }^{5}$, Лудовит Гаспар ${ }^{1}$}

\footnotetext{
1 Первая кафедра внутренних болезней, Медицинский факультет, Университет Комениуса, Братислава, Словакия

2 Кафедра клинической медицины, Отдел Образование, Тринити-колледж Дублин, Дублин, Ирландия

${ }^{3}$ Университет Овьедо, Центральная университетская больница Астуриас (ЦУБА), Овьедо, Испания

${ }^{4}$ Лаборатория структурной биологии и протеомики, Университет ветеринарных и фармацевтических наук, Брно, Республика Чехия

5 Кафедра функциональных наук, Направление патофизиология, Университет медицины и фармации „Виктор Бабеш“, Тимишоара, Румыния
}

Адрес для корреспонденции: Петер Крузлиак, Кафедра химических препаратов, Фармацевтическй факультет, Университет ветеринарныхи фармацевтических наук, ул. „Палакехо“ 1946/1, 61242 Брно, Республика Чехия E-mail: peter.kruzliak@savba.sk Тел: +420543181111

Дата получения: 12 декабря 2016

Дата приемки: 21 декабря 2016 Дата онлайн публикации: 19 мая 2017

Дата публикации: 29 сентября 2017

Ключевые слова: вариабельность уровня глюкозы, индекс MAGE, осложнения сахарного диабета

\section{Образец цитирования:}

Caprnda M, Mesarosova D, Ortega $\mathrm{PF}$, Krahulec B, Egom E, Rodrigo L, Kruzliak P, Mozos I, Gaspar L. Glycemic variability and vascular complications in patients with type 2 diabetes mellitus.

Folia Medica 2017;59(3):270-278. doi: 10.1515/folmed-2017-0048
Введение: Наличие макро- и микрососудистых осложнений у пациентов с сахарным диабетом (СД) не только связывается с хронической гипергликемией, представленной гликированным гемоглобином (HbA1c), но также и с резкими гликемическими колебаниями (гликемической вариабельностью, ГВ). Взаимосвязь между ГВ и осложнениями СД полностью не выявлена. Целью нашего исследования является измерение индекса MAGE ГВ у пациентов с СД 2-ого типа и подтверждение взаимосвязи индекса MAGE с наличием микро- макрососудистых осложнений СД.

Методы: 99 пациентов с СД 2-ого типа приняли участие в исследовании. Каждому пациенту был составлен подробный гликемический профиль, на основе которого был установлен индекс MAGE. Были проведены антропометрические измерения, оценка $\mathrm{HbA1c} \mathrm{и} \mathrm{уровня} \mathrm{глюкозы} \mathrm{в} \mathrm{плазме} \mathrm{крови} \mathrm{натощак}$ (УГПКН), оценка макрососудистых (ишемическая болезнь сердца - ИБС; заболевание периферических артерий - ЗПА; мозговой инсульт - МИ) и микрососудистых (диабетическая ретинопатия - ДР; нефропатия - ДН; периферическая нейропатия - ДПН) осложнений СД.

Результаты: Средний показатель индекса MAGE составил $5.15 \pm 2.88$ ммол/л., не установлены значительные различия показателей индекса MAGE в подгруппах в отношении наличия ИБС, МИ, ЗПА или ДР, ДН, ДПН. Показатель индекса MAGE в значительной степени коррелирует положительно с FPG ( $\mathrm{p}<$ 0.01) и НbA1c ( $<0.001)$ и отрицательно с весом $(p<0.05)$.

Заключение: В нашем исследовании не установлена взаимосвязь между индексом MAGE и наличием микрососудистых и макрососудистых осложнений у пациентов с СД 2-ого типа. Независимо от этого, данный отрицательный результат не отвергает категорически значение гликемической вариабельности в патогенезе диабетических осложнений. 